\title{
Lotka Volterra Model Simulation for Rice-field Rat and Tyto Alba Owls in Sumpiuh District, Banyumas Regency, Central Java
}

\author{
Reza Kusuma Nurrohman ${ }^{1 *}$, A. Ardiansyah ${ }^{2}$, Bayu Dwi Apri Nugroho ${ }^{3}$ \\ 1,3Department of Agricultural and Biosystem Engineering, Faculty of Agricultural Technology, \\ Universitas Gadjah Mada, Jl. Flora No. 1, Bulaksumur, Yogyakarta 55281, Indonesia \\ 2Department of Agricultural Engineering, Faculty of Agriculture, Universitas Jenderal Soedirman, \\ Jl. Dr. Soeparmo, Grendeng, Purwokerto Utara, Kabupaten Banyumas, Jawa Tengah 53122, Indonesia \\ *Email: reza.kusuma.n@mail.ugm.ac.id
}

Submission: June 2, 2019; Acceptance: August 20, 2019

\begin{abstract}
Rice-field rat (Rattus argentiventer) is a rodent that has a high level of productivity. These animals attack rice plants from the vegetative to the generative phase. This research aimed to analyze and to predict the accuracy of the use of owls with mathematical equations model in Kebokura and Lebeng villages, Sumpiuh district. Lotka Volterra and Competitive Lotka-Volterra models were used to predict the population dynamics of Owl (predator) and rice-field rats (prey), then Runge - Kutta numerical method was applied to analyze the population dynamics of predator and prey at a certain time. The results of the analyses using the Lotka - Volterra, Competitive Lotka - Volterra equations and simulation data, each graph data showed that the rats' population was able to be maximally suppressed. Based on the analysis result, started with 24 owls and 1,689 rats, the rats' population could be suppressed to 104 using Lotka - Volterra, and to 176 using the Competitive Lotka - Volterra model. Then in the first and second simulation, started with 50 and 100 owls and 1,689 rats, analysis using Lotka - Volterra and Competitive Lotka - Volterra showed that the rat population could be suppressed to as much as 126, 188 and 145, 189 , respectively. Based on the analysis, it could be concluded that use of Serak Jawa owl strategy was able to reduce and stabilize the rat populations. Furthermore, the higher population of owls can prevent the population explosion of rats and can suppress the rat population to a lower number.
\end{abstract}

Keywords: Lotka - Volterra; rice-field rat; Runge - Kutta algorithm; Tyto alba owl

\section{INTRODUCTION}

Rice-field rat (Rattus argentiventer) are often found to damage food crops, especially rice paddy. Rice-field rat can reproduce from 1.5 to 5 months, and a female rat gives birth to an average of 8 children per childbirth, and is able to mate again within 48 hours and be able to conceive while breastfeeding at the same time. For a year a female can give birth 4 times, so that in one year can be born 32 rats (Agriculture Department, 2013).

With a high population, rice-field rat can cause considerable rice crop damage resulting in decreased rice production and farmer losses. This happened at Sleman DI Yogyakarta, 7,200 Ha of paddy fields attacked by rice-field rat and resulted in production losses up to 1,000 tons precisely decreased $0.98 \%$ from 109,724 tons in 2012 and in 2013 to 108,363 tons (Bernas Jogja, 2013).

There are several methods to overcome rice-field rat attack, among others: a) Planting rice in unison; b) habitat sanitation; c) Gropyok masal; d) Fumigation; e) Rodenticides; and f) Trap Barrier System (TBS). However, some of these methods have some deficiency, among others, not all farmers or farmer groups are willing to plant rice in unison. Methods of sanitation and gropyok masal require a lot of manpower, fumugation is usually done after the attack. The use of rodenticides is quite effective when the rat population is large but if the rice field area is close to the residential area, the rats will most likely die in people's homes and cause an unpleasant odor because the rodenticide toxins work slowly at 48 hours, around including humans (Pardosi, 
2005). Than, the Trap Barrier System method requires a trap that is routinely installed in paddy fields.

Agricultural Department of Banyumas District is developing a method of rice-field rat control by using natural enemies, namely Serak Jawa (Tyto alba) because it is considered potential and has advantages compared to other methods. In accordance with the Agricultural Department of Banyumas District program, subdistrict Sumpiuh also apply that method on agricultural land in their region, precisely in the village of Lebeng and Kebokura. The use of owl methods is more economical and ergonomic, because it requires a small cost and does not require human intervention to control the rat population. The Serak Jawa owls can effectively control the rats because the specific foods are rats (99\%) and insects (1\%) (Morris, 1979; Duckett, 1991). Consumption power reaches 2-4 rats / day / owl (Lenton, 1980; Sipayung et al., 1990). In addition, Serak Jawa owl performs its activities at night from 19:00 to 06:00 am which coincides with the activity of rats.

The use of owl methods has many advantages and has long been applied, but not known specifically how the strategy of using owl as a method of rice-field rat control. Such strategies include; how many owls are needed for a given land area or a certain number of mouse populations, how to stabilize the rat population to keep it low, so that it has low damage power at least without disturbing the balance of the ecosystem.

The purpose of this research was to analyze the strategy to control rice-field rats using the Serak Jawa owls with the calculation of Predator-Prey model simulation using the Lotka Volterra and Competitive Lotka Volterra equations, and to make a simulation with the addition of the number of predators, then make a comparison with actual data to determine the factors of the initial number of predators against the dynamics of rat populations.

\section{METHODS}

\section{Study Area}

The study area is in Sumpiuh District, one of districts area in Banyumas Regency, Central Java, Indonesia (Figure 1). Location of Sumpiuh District ( $7^{\circ} 32^{\prime} 18.1^{\prime \prime S}$ - 7039'47.9"S, 109²4'05.3"E - 109¹9'45.1"E) and bordering with Somagede, Tambak, Nusawungu, Kemranjen Subdistrict in north, east, south and west, respectively. The total area of Sumpiuh approximately $103 \mathrm{~km}^{2}$ or equivalent to $10,300 \mathrm{ha}$.

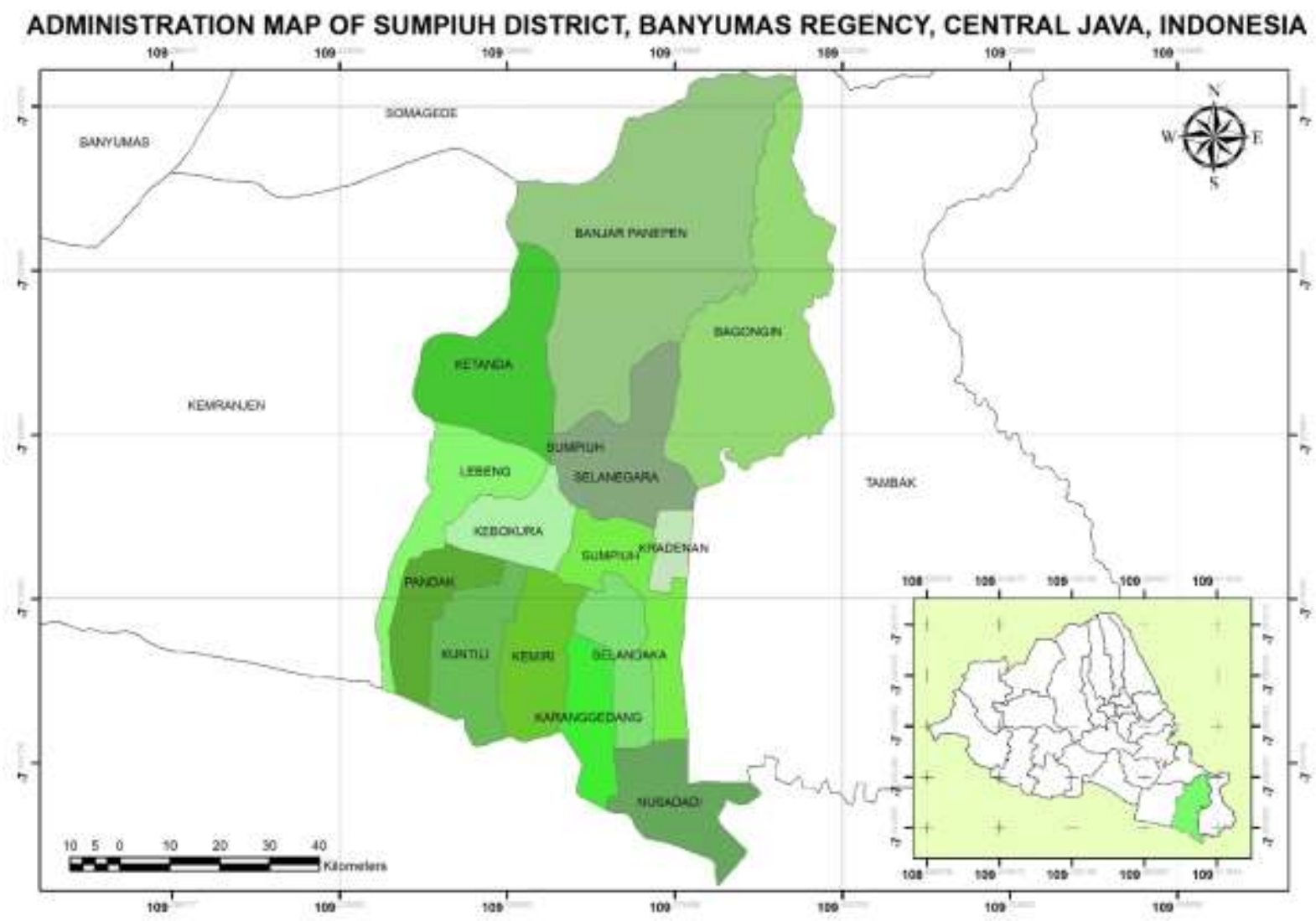

Figure 1. Administration map of Sumpiuh District, Banyumas Regency, Central Java, Indonesia 


\section{Data and Analytical Method}

Data that used in this research is the data of application of owl house in Sumpiuh District that obtained from Agricultural Department of Banyumas Regency, Land use map, Lotka-Volterra and Competitive Lotka-Volterra equation coefficient that obtained from calculation and reference from other research.

Method that used in this research is using LotkaVolterra and Competitive Lotka-Volterra equation to know the value of competition between owl and ricefield rat, then do a simulation by predicting using Runge Kutta numerical method that performed on Visual Basic Microsoft Excel, and ArcGIS software is used to display data spatially.

The Lotka-Volterra equation was first introduced by Lotka and Volterra in 1925, with the Equation 1 and 2.

$$
\begin{gathered}
\frac{d N_{1}}{d t}=a N_{1}-b N_{1} N_{2} \\
\frac{d N_{2}}{d t}=-c N_{2}+d b N_{1} N_{2}
\end{gathered}
$$

Where $N_{1}$ is the population of the Predator, $N_{2}$ is the population of the Prey, $a$ is the coefficient of birth rate of the population of Prey, $b$ is the coefficient of predation level, $\mathrm{c}$ is the mortality rate of the Predator population, and $\mathrm{d}$ is the Predator reproduction.

The Competitive Lotka - Volterra is basically the same as the Lotka-Volterra equation such as Eq. 1 and Eq. 2, but on the competitive model, two coefficients are added ie a (reproduction rate of prey in its territory) and $\beta$ (action of reproduction of prey) (Willson, 2010), with the Equation 3 and 4.

$$
\begin{gathered}
\frac{d N_{1}}{d t}=a N_{1}-b N_{1} N_{2}-\alpha\left(N_{1}\right)^{2} \\
\frac{d N_{2}}{d t}=-c N_{2}+d b N_{1} N_{2}-\beta\left(N_{2}\right)^{2}
\end{gathered}
$$

The Runge-Kutta method is a method used to solve numerical differential equations or approaches so as to obtain solutions representing a complete or analytical solution (Chitode, 2010). In order to obtain the dynamics of the Owl and Rice-field rat population, the Lotka-Volterra and Competitive Lotka-Volterra is solved using the Runge-Kutta numerical method, so that the following two differential equations can be obtained (Butcher, 2008). The Runge-kutta equation as follows (Equation 5 and 6).

$$
\begin{aligned}
\frac{d N_{1}}{d t} & =F(x, y, z) \\
\frac{d N_{2}}{d t} & =G(x, y, z)
\end{aligned}
$$

Then completed the Runge-Kutta method for each order (Nugroho, 2009). To obtain Predator and Prey population numbers at the next time step, we use the n-order Runge-Kutta equation, as in the Equation 7 and Equation 8.

$$
\begin{aligned}
& N_{1_{n+1}}=N_{1}+\frac{K_{1}+2 K_{2}+2 K_{3}+K_{4}}{6} \\
& N_{2_{n+1}}=N_{2}+\frac{K_{1}+2 K_{2}+2 K_{3}+K_{4}}{6}
\end{aligned}
$$

The next step is to do the simulation twice, compare the calculation of Lotka-Volterra and Competitive LotkaVolterra equations with real data and simulation data. Based on the simulation results it can be seen the exact and optimal number of owls to be applied in the research location.

\section{RESULTS AND DISCUSSIONS}

\section{Coefficient of Lotka-Volterra and Competitive Lotka-Volterra Equations}

The Coefficient of Lotka-Voltera equation consists of $a, b, c$, and $d$. The coefficient value depends on the prey rate of birth (a), predator mortality (b), mortality rate of predator population (c), and predator reproduction after prey (d).

The population of rats in Banyumas District reached 900 / 105 ha of paddy fields (Winarto, 2018), and rice-field rat has a birth rate of 32 per year annually (Agriculture Department, 2013). Rice field in Sumpiuh Subdistrict has an area of 1,604 ha and in the village of Kebokura and Lebeng has an area of 197 ha. Application of the owl method to overcome rice-field rat, located in

Table 1. The value of predator-prey coefficient with Lotka-Volterra equation

\begin{tabular}{llllll}
\hline Case & a & b & c & d & Reference \\
\hline Canadian Lynx - Snowshoe Hare & 1 & 0.03 & 0.4 & 0.01 & (Ondum, 1953) \\
Wolf - Rabbit & 1 & 0.21 & 0.5 & 0.04 & (Kumar, 2006) \\
Fox - Rabbit & 0.4 & 0.001 & 0.001 & 0.9 & (Lundin, 2011) \\
\hline
\end{tabular}


Table 2. The value of predator-prey coefficient of Serak Jawa Owl and Rice-field Rat

\begin{tabular}{lllllllll}
\hline Model & $\mathrm{N}_{1}$ & $\mathrm{~N}_{2}$ & $\mathrm{a}$ & $\mathrm{b}$ & $\mathrm{c}$ & $\mathrm{d}$ & $\mathrm{a}$ & $\beta$ \\
\hline Lotka-Volterra & 1,689 & 24 & 32 & 0.21 & 60 & 0.5 & - & - \\
Competitive Lotka-Volterra & 1,689 & 24 & 32 & 0.21 & 60 & 0.5 & 0.0087 & 0.0011 \\
\hline
\end{tabular}

Kebokura and Lebeng villages, Sumpiuh sub-district in 2015. Based on the data, the rat population in the land area of 197 ha can be assumed, the rats population are 1,689 . As an effort to overcome rice-field rat, at some point in the location of rice field has been placed 12 cages of owl house (rubuha) or 24 owls (one pair per owl house).

Animals that used as a predator for rice-field rat are the Serak Jawa Owl (Ruyyschaert et al., 2011) which have the longest life span of 37 years and have a reproductive rate once a year but can be two to three times a year depending on the food supply and usually spawn 2 - 18 points (Marti, 1992). Owl age ranges from 34 years (Harris, 2002) and even up to 60 years if treated well (Anonim, 2016).

Coefficient value $a=32$ (Agricultural Department, 2013); $c=60 ; d=0.5$ (comparison between predator birth and prey birth); $b=0.21$ using coefficient according to (Kumar, 2006). Selection of coefficient values due to similarity of predation rate with owl, the owl preys 2-4 rat per day, then the wolves prey on 1-2 rabbits a day, and the wolf-like owls are preyed at night because wolves have a reflective retina (Tapetum) that helps sharpen the vision of wolves at night day (Sandra, 2010; Catharina, 2010). The values of $a$ and $\beta$ are derived from prey reproduction in its territory $(32 / 365)$ / 10) and predator consumption on prey reproduction $((4 / 365) / 10)$, resulting in values $a=0.0087 ; \beta=$ 0.0011 . So the coefficient value obtained as in Table 2 .

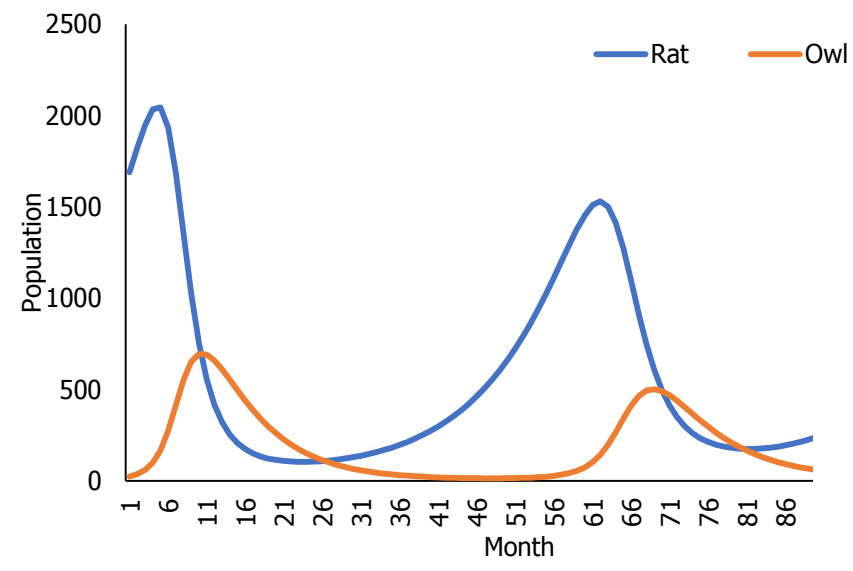

Figure 2. Dynamic population of owls and rats using the Lotka Volterra equation

\section{Actual Data Analysis Using Lotka-Volterra and Competitive Lotka-Volterra Equations}

Based on the analysis using data in the Table 2 for Lotka-Volterra and Competitive Lotka-Volterra equation, has been obtained the dynamics data of owl population and rice-field rat that can be seen in Figure 2.

Figure 2 shows that the rat population had risen up until 2,045 in the $5^{\text {th }}$ month but able to be suppressed optimally until 104 rats in the $23^{\text {rd }}$ month, then fluctuate and then the rat population increased in the $62^{\text {nd }}$ month with 1,530 rats, but can be controlled by owls again.

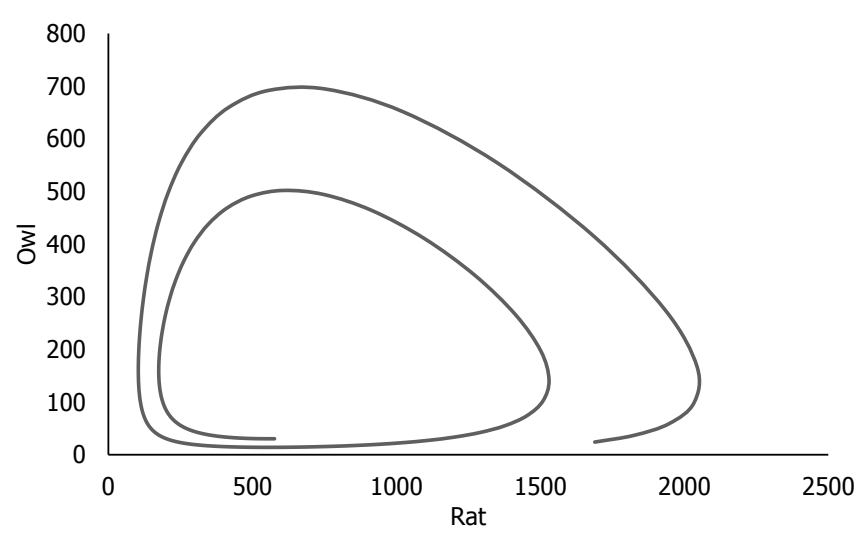

Figure 3. Phase space plot of owls and rat using Lotka-Volterra equation

The owl population also increased twice, up to 694 and 501 at $10^{\text {th }}$ and $69^{\text {th }}$ month, respectively. Based on the results of the analysis, owls are able to control the ricefield rat population significantly.

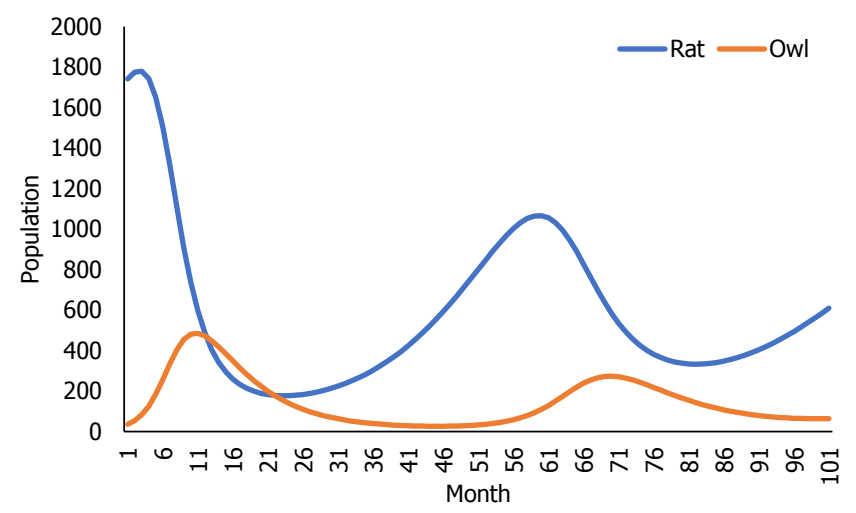

Figure 3. Phase space plot of owls and rat using Lotka-Volterra equation 
Based Figure 3, the competition between owls and rats, that owls are able to suppress the rat population well, from 1,$689 ; 2,045 ; 104 ; 1,530$ and 174 , respectively and continue to decline.

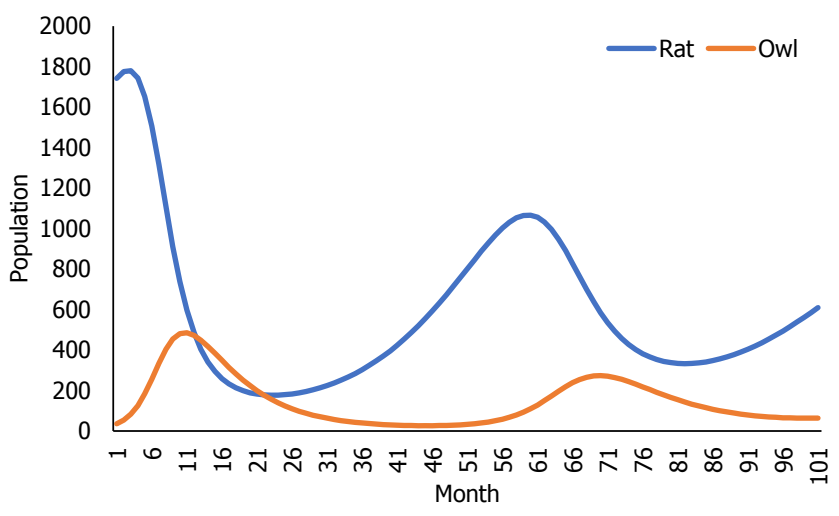

Figure 4. Dynamic population of owls and rats using the competitive Lotka Volterra equation

Figure 4 shows that the rat population had risen up until 1,779 in the $4^{\text {th }}$ month but able to be suppressed optimally until 176 rats in the $24^{\text {th }}$ month, then fluctuate and then the rat population increased in the $61^{\text {st }}$ month with 1,066 rats, but can be controlled by owls again. The owl population also increased twice, up to 485 and 273 at $12^{\text {th }}$ and $71^{\text {st }}$ month, respectively. Based on the results of the analysis, owls are able to control the rice-field rat population, evidenced by declining rat populations of each cycle.

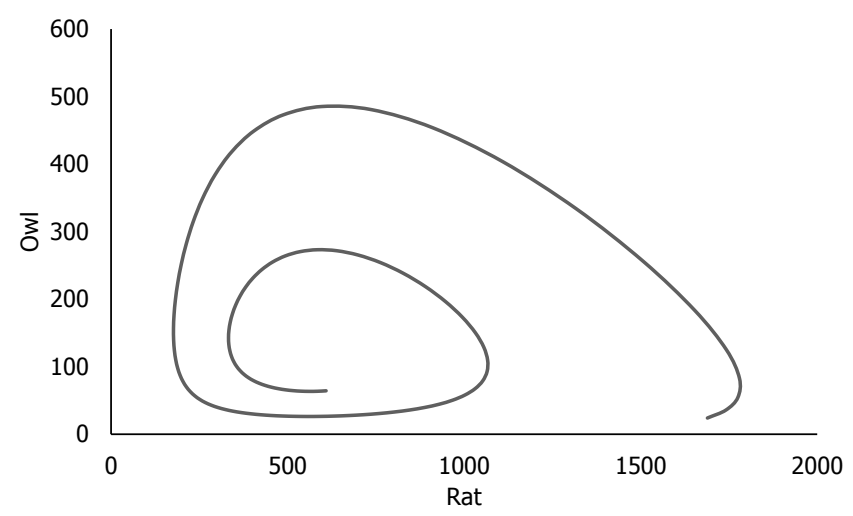

Figure 5. Phase space plot of owls and rat using competitive Lotka-Volterra equation
Based on the graph (Figure 5), it can be seen the competition between owls and rats, that owls are able to suppress the rat population very well, from 1,$689 ; 1,779$ and $176 ; 1,066 ; 332$ respectively continue to decline each cycle and possibly stable at 500 rats population.

\section{First Simulation Analysis Using Lotka-Volterra and Competitive Lotka-Volterra Equations}

The simulation is performed by replacing the initial value of the owl number, this simulation is to model the relationship between owl and rat, in an effort to find the optimal of initial predator value.

Based on the simulation analysis using data in the Table 3 and Lotka-Volterra and Competitive LotkaVolterra equation, has been obtained the dynamics data of owl population and rice-field rat that can be seen in Figure 6.

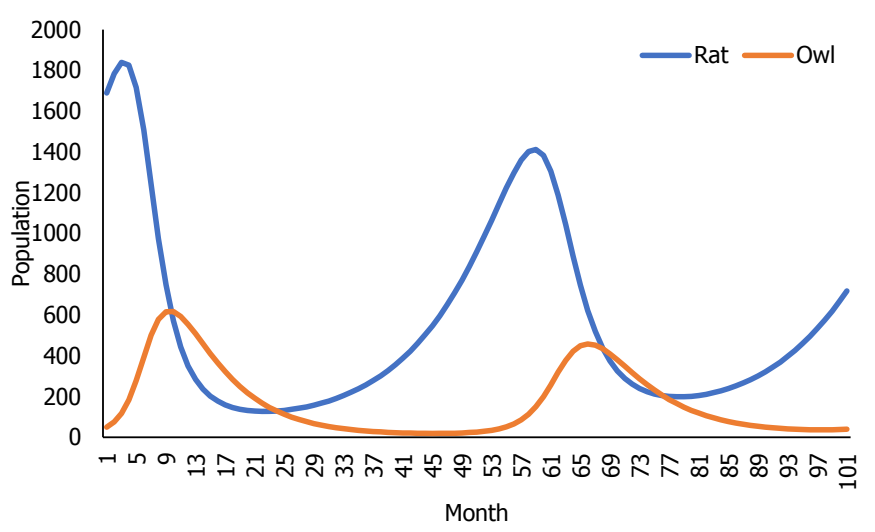

Figure 6. Dynamic population simulation 1 of owls and rats using the Lotka Volterra equation

The graph (Figure 6) shows that the rat population had risen up until 1,839 in the $3^{\text {rd }}$ month, than able to decreased until of 126 rats in the $22^{\text {nd }}$ month, then fluctuate and then the rat population increased in the $59^{\text {th }}$ month with 1,412 rats, but can be controlled by owls again. The owl population also increased twice, up to 616 and 458 at $10^{\text {th }}$ and $66^{\text {th }}$ month, respectively. Based on the results of the analysis, owls are able to control the rice-field rat population significantly.

Table 3. The Value of predator-prey coefficient of Serak Jawa owl and rice-field rat in simulation 1

\begin{tabular}{lllllllll}
\hline Simulation 1 & $\mathrm{N}_{1}$ & $\mathrm{~N}_{2}$ & $\mathrm{a}$ & $\mathrm{b}$ & $\mathrm{c}$ & $\mathrm{d}$ & $\mathrm{a}$ & $\beta$ \\
\hline Lotka-Volterra & 1,689 & 50 & 32 & 0.21 & 60 & 0.5 & - & - \\
Competitive Lotka-Volterra & 1,689 & 50 & 32 & 0.21 & 60 & 0.5 & 0.0087 & 0.0011 \\
\hline
\end{tabular}




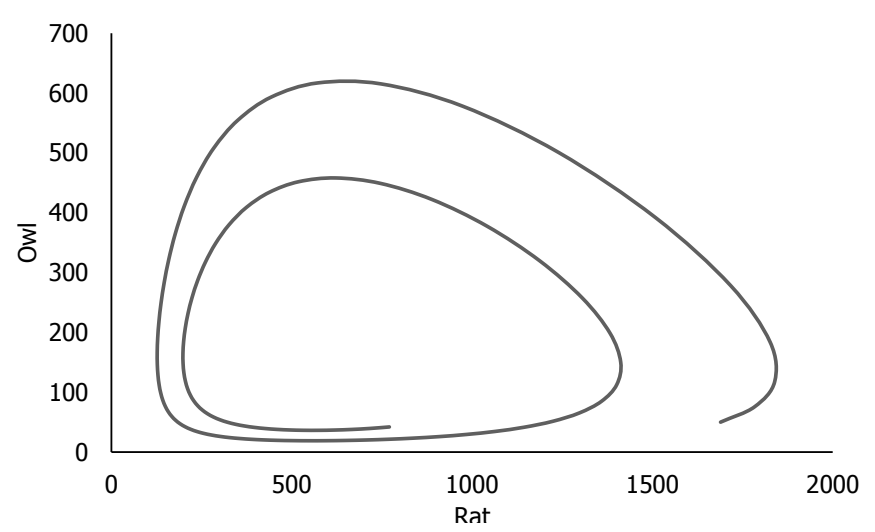

Figure 7. Phase space plot simulation 1 of owls and rat using Lotka-Volterra equation

Based on the graph (Figure 7) it can be seen the competition between owls and rats, that owls are able to suppress the rat population well, from 1,689, 1,839, $126,1,412$ and 198 , respectively and continue to decline each cycle and possibly stable at 750 rats population.

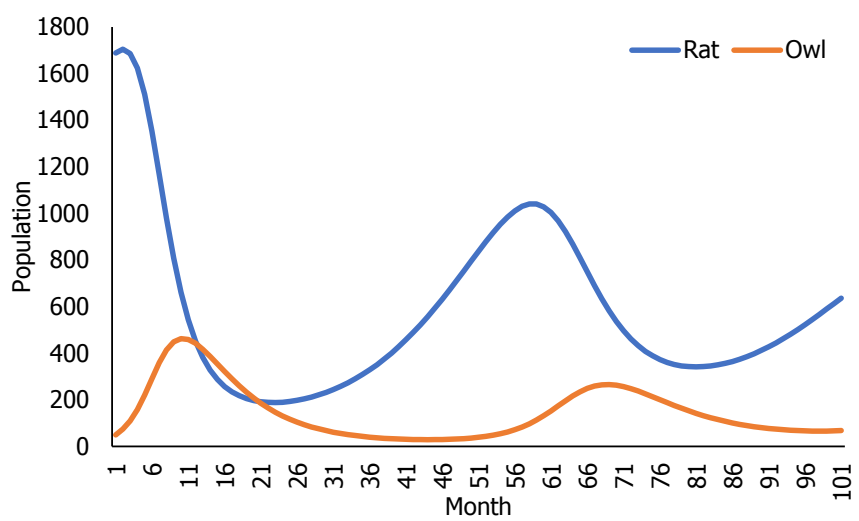

Figure 8. Dynamic population simulation 1 of owls and rats using the competitive Lotka Volterra equation

The graph (Figure 8) shows that the rat population had risen up until 1,704 in the $2^{\text {nd }}$ month, than able to decreased until of 188 rats in the $22^{\text {nd }}$ month, then fluctuate and then the rat population increased in the $58^{\text {th }}$ month with 1,040 rats, but can be controlled by owls again. The owl population also increased twice, up to 462 and 265 at $10^{\text {th }}$ and $69^{\text {th }}$ month, respectively.

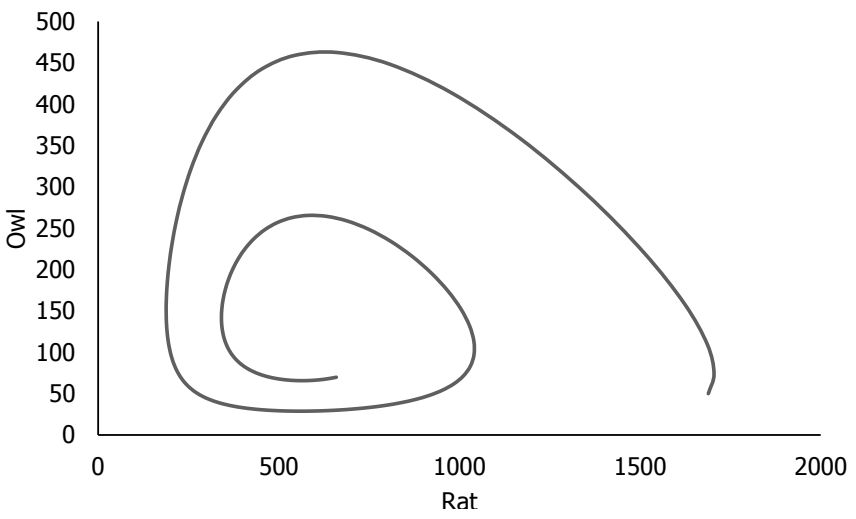

Figure 9. Phase space plot simulation 1 of owls and rat using competitive Lotka-Volterra equation

Based on the results of the analysis, owls are able to control the rice-field rat population.

Based on the graph (Figure 9) it can be seen the competition between owls and rats, that owls are able to suppress the rat population very well, from 1,689 , $1,704,188,1,040$ and 341 , respectively to decline each cycle and possibly stable at 600 rats population.

\section{Second Simulation Analysis Using Lotka-Volterra and Competitive Lotka-Volterra Equations}

The second simulation is performed by replacing the initial value of the owl with the higher number, this simulation is to model the relationship between owl and rat, in an effort to find the optimal of initial predator value.

Based on the simulation analysis using data in the Table 4 and Lotka-Volterra and Competitive LotkaVolterra equation, has been obtained the dynamics data of owl population and rice-field rat that can be seen in the Figure 10.

The graph (Figure 10) shows that the rat population had risen up until 1,708 in the $2^{\text {nd }}$ month, than able to decreased until of 145 rats in the $21^{\text {st }}$ month, then fluctuate and then the rat population increased in the $56^{\text {th }}$ month with 1,334 rats, but can be controlled by owls again. The owl population also increased twice, up to 568 and 427 at $8^{\text {th }}$ and $64^{\text {th }}$ month, respectively. Based on the results of the analysis, owls are able to control the rice-field rat population.

Table 4. The value of predator-prey coefficient of Serak Jawa owl and rice-field rat in simulation 2

\begin{tabular}{lllllllll}
\hline Simulation 2 & $\mathrm{N}_{1}$ & $\mathrm{~N}_{2}$ & $\mathrm{a}$ & $\mathrm{b}$ & $\mathrm{c}$ & $\mathrm{d}$ & $\mathrm{a}$ & $\beta$ \\
\hline Lotka-Volterra & 1,689 & 100 & 32 & 0.21 & 60 & 0.5 & - & - \\
Competitive Lotka-Volterra & 1,689 & 100 & 32 & 0.21 & 60 & 0.5 & 0.0087 & 0.0011 \\
\hline
\end{tabular}




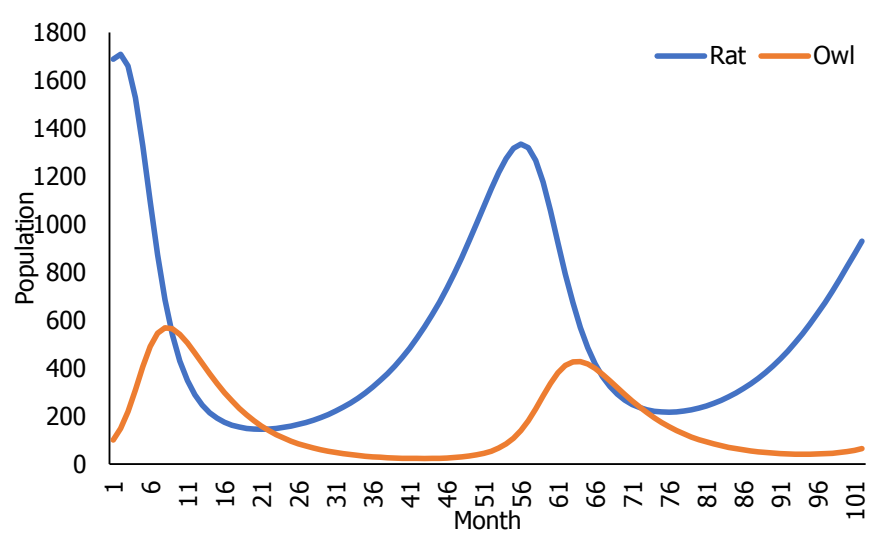

Figure 10. Dynamic population simulation 2 of owls and rats using the Lotka Volterra equation

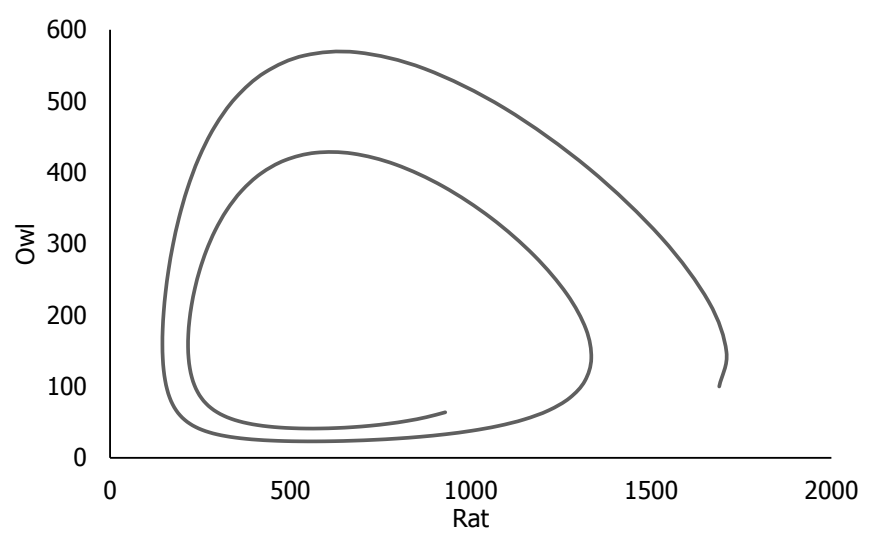

Figure 11. Phase space plot simulation 2 of owls and rat using Lotka-Volterra equation

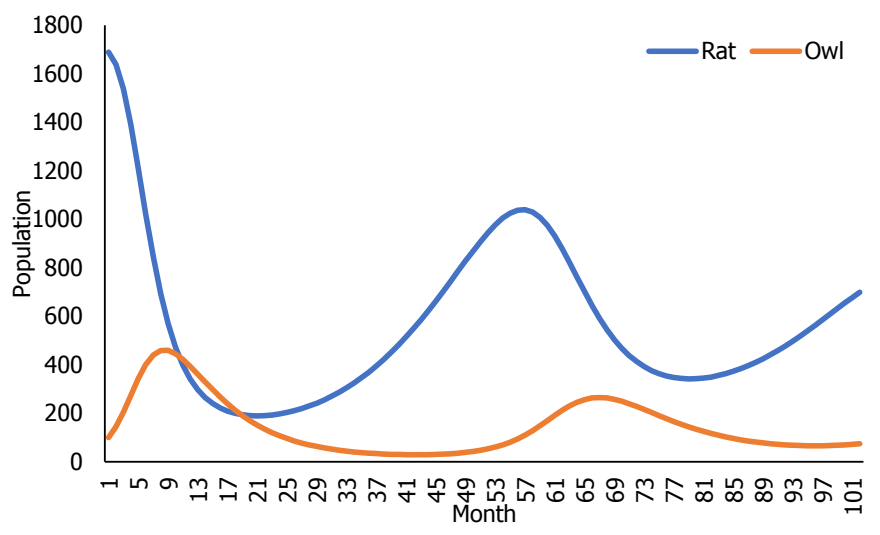

Figure 12. Dynamic population simulation 2 of owls and rats using the competitive Lotka Volterra equation

Based on the graph (Figure 11) it can be seen the competition between owls and rats, that owls are able to suppress the rat population well, from $1,689,1,708$, $145,1,334$ and 216 , respectively and continue to decline each cycle and possibly stable at 600 rats population.

The graph (Figure 12) shows that the rat population is decreased until of 189 rats in the $21^{\text {st }}$ month, then fluctuate and then the rat population increased in the $57^{\text {th }}$ month with 1,039 rats, but can be controlled by owls again. The owl population also increased twice, up to 459 and 265 at $8^{\text {th }}$ and $67^{\text {th }}$ month, respectively. Based on the results of the analysis, owls are able to control the rice-field rat population significantly and without an increase of initial rat population.

Table 5. Comparison of parameter and analysis results using Lotka-Volterra and competitive Lotka-Volterra equation

\begin{tabular}{|c|c|c|c|c|c|c|}
\hline \multirow{2}{*}{$\begin{array}{l}\text { Parameter } \\
\text { Initial population of owl }\end{array}$} & \multicolumn{2}{|c|}{ Actual data } & \multicolumn{2}{|c|}{ Simulation 1} & \multicolumn{2}{|c|}{ Simulation 2} \\
\hline & 24 & & 50 & & 100 & \\
\hline Initial population of rat & 1,689 & & 1,689 & & 1,689 & \\
\hline $\mathrm{a}$ & 32 & & 32 & & 32 & \\
\hline b & 0.21 & & 0.21 & & 0.21 & \\
\hline c & 60 & & 60 & & 60 & \\
\hline$d$ & 0.5 & & 0.5 & & 0.5 & \\
\hline$a$ & 0.0087 & & 0.0087 & & 0.0087 & \\
\hline$\beta$ & 0.0011 & & 0.0011 & & 0.0011 & \\
\hline Equation & $\begin{array}{l}\text { Lotka } \\
\text { Volterra }\end{array}$ & $\begin{array}{l}\text { Competitive } \\
\text { Lotka Volterra }\end{array}$ & $\begin{array}{l}\text { Lotka } \\
\text { Volterra }\end{array}$ & $\begin{array}{l}\text { Competitive } \\
\text { Lotka Volterra }\end{array}$ & $\begin{array}{l}\text { Lotka } \\
\text { Volterra }\end{array}$ & $\begin{array}{l}\text { Competitive } \\
\text { Lotka Volterra }\end{array}$ \\
\hline Maximum population of owl & 649 & 485 & 616 & 462 & 568 & 459 \\
\hline Second owl population peak & 501 & 273 & 458 & 265 & 427 & 265 \\
\hline Minimum population of owl & 13 & 26 & 18 & 28 & 23 & 28 \\
\hline Maximum population of rat & 2,045 & 1,779 & 1,839 & 1,704 & 1,708 & 1,689 \\
\hline Second rat population peak & 1,530 & 1,066 & 1,412 & 1,040 & 1,334 & 1,039 \\
\hline Minimum population of rat & 104 & 176 & 126 & 188 & 145 & 189 \\
\hline
\end{tabular}




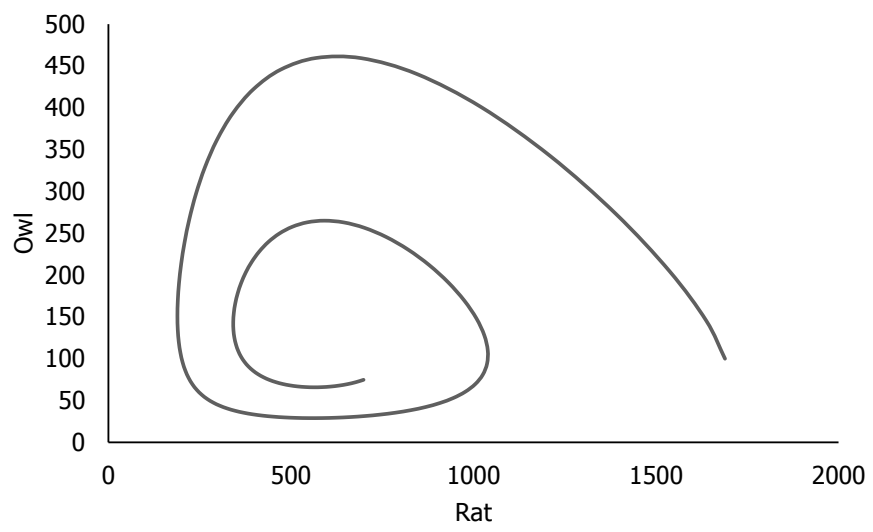

Figure 13. Phase space plot simulation 2 of owls and rat using competitive Lotka-Volterra equation

Based on the graph (Figure 13) it can be seen the competition between owls and rats, that owls are able to suppress the rat population well, from 1,689, 189, 1,039 and 341 , respectively and continue to decline each cycle and possibly stable at 600 rats population.

\section{Comparison Between Actual And Simulation Data Analysis}

Comparison of actual and simulation data analysis results is performed to find out in detail, the most appropriate method to be used in the analysis and prevention or controlling of rat on rice-field.

The higher the owl population at the beginning, can prevent the rat population explosion and owls themselves, because at the beginning of the number of rat is adequate, the rat population decreased dramatically and the owl population increased, but when the rat population is low, the owl population also decreased as the number of owl food becomes scarce.

Proven in the early years, based on the analysis result with the higher number of owls are able to reduce the population of rats quickly, and still able to control and suppress the population in low numbers, with little difference between the real data and the simulation data, i.e. 5 rats.

Based on the results of real data analysis and two simulations, it is recommended to use owls in comparison between owls and rat 2: 140 (if known the number of rat in the fields). Based on the territorial coverage of the owls that reaches $1 \mathrm{~km}$ (Taylor, 2004), it can be described the application of owl house/ rubuha in rice fields of Kebokura and Lebeng villages as follows in the Figure 14.

With the number of initial owls and proper owl house placement, it can be lowered the rat population

\section{OWL HOUSE IMPLEMENTATION MAP IN KEBOKURA AND LEBENG VILLAGES SUMPIUH DISTRICT, BANYUMAS REGENCY, CENTRAL JAVA, INDONESIA}

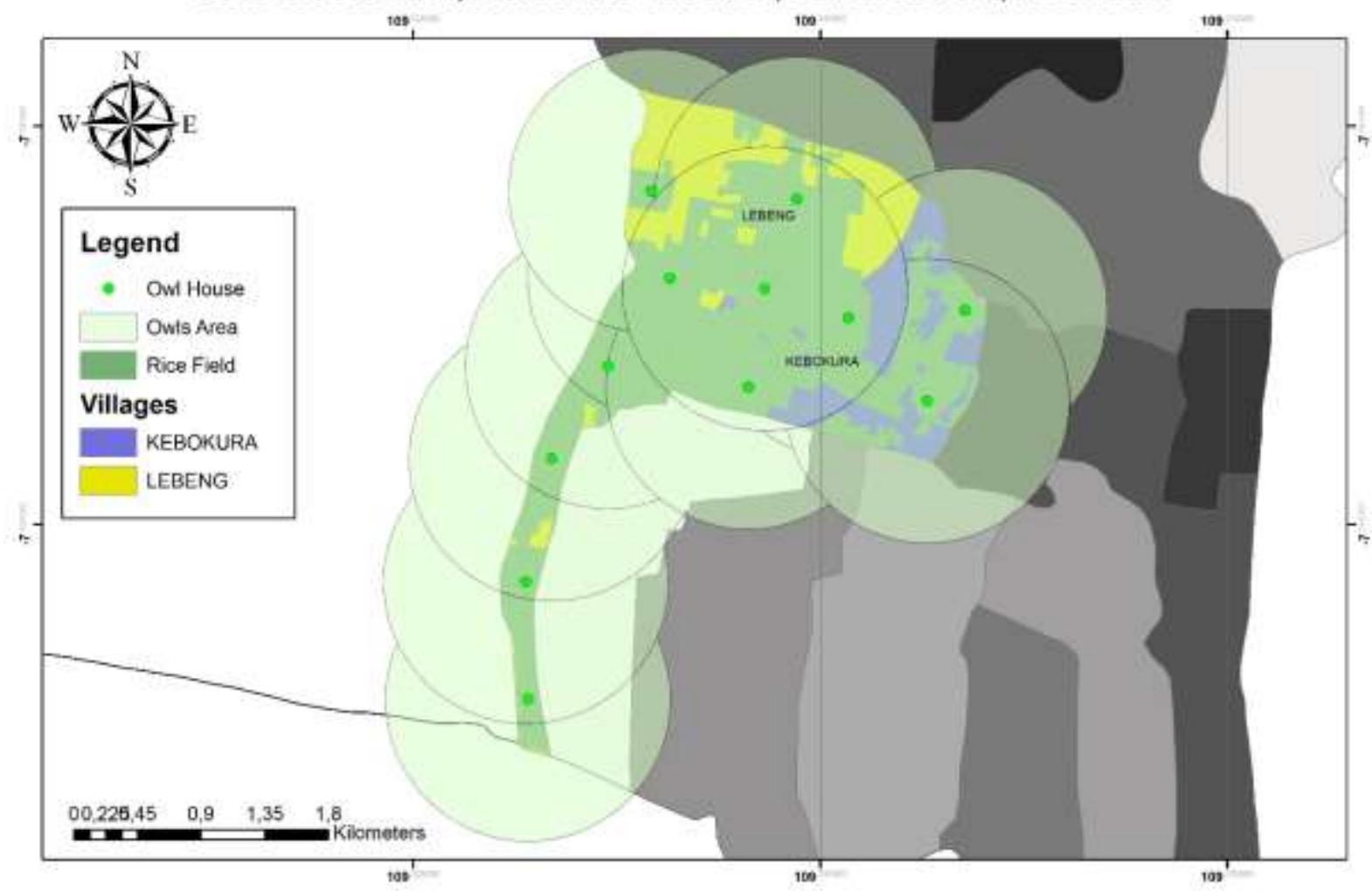

Figure 14. Owl house implementation map in Kebokura and Lebeng Villages 


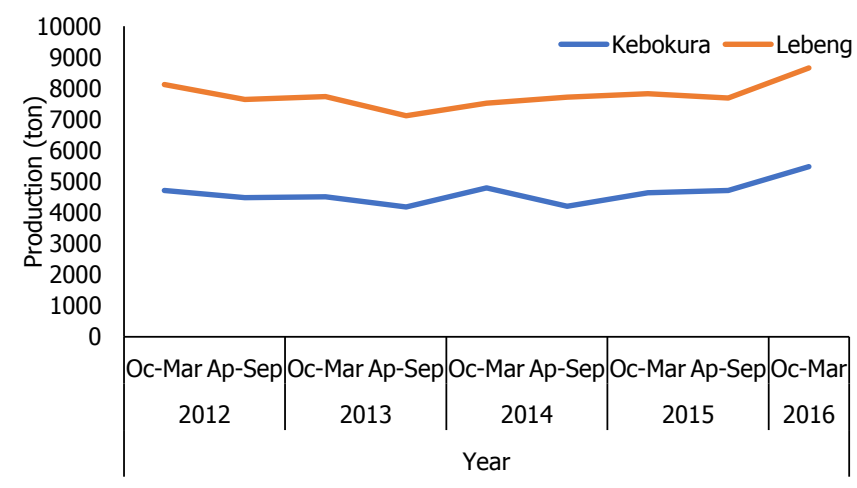

Figure 15. Rice production graph in the Kebokura and Lebeng Village (2012-2016)

and able to control the rat population quickly if there is an increase of rat population and prevent the occurrence of a rats population explosion, which capable of attacking huge areas of rice fields that can cause high damage.

In the rice fields of Kebokura and Lebeng villages, along with the owl method, farmers use Trap Barrier System (TBS). Both methods can be used simultaneously because it does not interfere with each other. Never use rat poison when applying the owl method, because it can kill the owls that eat the poisonous rat. With these recommendations, the effectiveness of the use of natural enemies can be more optimal and able to reduce rat populations more leverage.

Driesche et al. (2009) also said that efficacy of native or previously introduced predators can be enhanced through habitat modification. Adding nesting boxes for barn owls (Tyto alba) reduced crop damage from rats in Malaysian oil palm, in combination with rodenticide campaigns.

\section{Comparison of Paddy Production Before and after the Application of Owl Methods}

Paddy type that used in the Kebokura and Lebeng villages is situbagendit, and those villages have the same land and climate characteristic. Based on the obtained data from the Sumpiuh Agricultural Instructor Center, paddy production data from 2012 to 2016 can be seen in the following graph.

The owl method is applied in May 2015, proven on the planting time on April-September 2015, and OctoberMarch 2016 paddy production increased from 12,400 to $14,134.4$ ton, achieved the highest productivity during the last 4 years and most likely will continue to increase in the next harvest.

\section{CONCLUSIONS}

Using 24 Serak Jawa owls or one pair in each 12 owl house that placed precisely according to the owl range radius in the 197 ha rice field proved capable of reducing and controlling the rat population and can increase rice production (minimize the impact of pest damage). On the other hand, initial population number of owls greatly affect the dynamics of rat populations. Proved by the initial explosion of rat populations decreased in Simulation 1, and no more rat population explosion occurred in simulation 2. Higher initial owl population it can suppress the high rat population, but unable to suppress the rat population into lowest number.

\section{ACKNOWLEDGMENT}

We thank Banyumas Regency Agricultural Department and the Sumpiuh District Agricultural Instructor Center for the support of providing research data.

\section{CONFLICT OF INTEREST}

Authors declare that there was no conflict interest between authors and the founder.

\section{REFERENCES}

Anonim. (2016). Umur Dari Hidup Burung Hantu. Website : http://lintasmetro.com /2016/11/24/umur-dari-hidupburung-hantu/ (Accessed on 8 September 2017, at 21.45 WIB)

Agriculture Department. (2013). Pengendalian Tikus Sawah. Website: http://pangan. litbang.pertanian.go.id/berita836-pengendalian-tikus-sawah.html. (Accessed on 8 September 2017, at 21.50 WIB)

Bernas Jogja. (2013). 7.200 Ha Lahan Diserang Tikus. Koran Bernas Jogja Sabtu pon 4 Desember 2013. Halaman 3.

Butcher J. C. (2008). Numerical Method for Ordinary Differential Equation (Second edition). British Library Cataloguing in Publication Data. Page 93 - 103. ISBN : 978-0-470-72335-7.

Catharina S. Siefken C. (2010). Seasonal Changes in The Tapetum Lucidum as and Adaption to Winter Darkness in Reindeer. University of Tromso : Faculty of Biosciences, Fisheries and Economics, Department of Arctic and Marine Biology.

Chitode J. S. (2010). Numerical Methods. Technical Publication Pune; Amit Residency India. Page 4-42.

Driesche, R. V., Mark H., \& Ted C. (2009). Control of Pests and Weeds by Natural Enemies: An Introduction to Biological Control. John Wiley \& Sons. Page 342.

Ducket, J. E. (1981). Barn Owls (Tyto alba) - a proven natural predator of rats in oil palm. In: Pushparajah, 
E \& Chew Poh Soon (eds). the oil palm in Agriculture in the Eighties.Vol. 2: pp. 461 - 473. Kuala lumpur: Incorporated Society Plant.

Harris, M. (2002). "Tyto alba" (On-line), Animal Diversity Web. Accessed September 08, 2017 at http://animaldiversity. org/accounts/Tyto_alba/

Kumar A. K., \& Ray A. (2006). Analysis of Adaptive Volterra Filters Alt LMS and RLS Algoritm. Department of Electronics and Communications Engineering. Thapar University, Patiala 147004 Punjab.

Lenton, G. M. (1980). Biological Control of Rats by Owl in Palm and Oter Plantation. Proceeding Symposium Small Mammals; Problem and Control Biotrap Special Publication. No. 12. 87 - 94 pp.

Lotka, A. J. (1925). Elements of physical biology. Baltimore: Williams \& Wilkins Co.

Lundin, J., Petter O., \& Vagberg, D. (2011). Modelling and Simulation. Computational Science and Engineering. Umea University

Morris, P. (1979). Rats in the diet of the Barn owl (Tyto alba). Journal of Zoology, 189, 540-545. doi: 10.1111/j.14697998.1979.tb03983.x

Nugroho, B. D. (2009). Diktat Kuliah Mx 211: Metode Numerik. Program Studi Matematika Fakultas Sains dan Matematika. Salatiga: Universitas Kristen Satya Wacana.

Ondum, E. P. (1953). Fundamentals of Ecology. Philadelphia: W. B. Saunders.
Pardosi, J. F., \& Bambang, S. (2005). Dosis Efektif dan Waktu Kontak Rodentisida Contrac 0,005 terhadap Tikus Putih (Mus sp.) di Laboratorium Entomologi Poltekes Jakarta II.

Sipayung A., Desmier de Chenon R., Sudharto P. (1989). Natural enemies of leaf-eating Lepidoptera in Oil Palm Plantations, North Sumatra. Biotrop Spec. Publ., 36, 99 $-121$.

Ruysschaert, Adji D., Rizwan Z., Gunung G., Ian S. (2011). Budidaya Kelapa Sawit di Lahan Tidur. Implikasinya terhadap aspek teknis, ekonomi, keanekaragaman hayati, iklim, hukum dan kebijakan. Medan: Yayasan Ekosistem Lestari (YEL).

Taylor, I. (2004). Barn Owls: Predator-prey Relationships and Conservation. Great Britain: Cambridge University Press. ISBN 978-0-521-54587-7.

Volterra, V. (1926). Variazioni e fluttuazioni del numero d'individui in specie animali conviventi. Mem. R. Accad. Naz. dei Lincei. Ser. VI, vol. 2.

Willson, W. (2010). Simulating Ecological and Evolutionary System in C. Duke University: Department of Zoology. Published by Cambridge University Press.

Winarto. (2018). Personal Communication. Sumpiuh District Agricultural Instructor Center. 16 January 2018. 